\title{
Educational group practices in primary care: interaction between professionals, users and knowledge*
}

\author{
Práticas educativas grupais na atenção básica: padrões de interação \\ entre profissionais, usuários e conhecimento \\ Prácticas educativas grupales en la atención básica: estándares de \\ interacción entre profesionales, usuarios y conocimiento
}

\author{
Maria Flávia Gazzinelli', Vânia de Souza², Rosa Maria Godoy Serpa da Fonseca ${ }^{3}$, Marconi Moura Fernandes ${ }^{4}$, Angélica \\ Cotta Lobo Leite Carneiro ${ }^{5}$, Luanna Kelen Godinho ${ }^{6}$
}

\footnotetext{
* Excerpt from the dissertations "Educational Practices in Basic Healthcare Units in Belo Horizonte and their Relation to the Promotion of Health" and "Educational Practices in Primary Care: A Case Study of Teaching Methods", School of Nursing, Universidade Federal de Minas Gerais, 2010/2011.

${ }^{1}$ Associate Professor, School of Nursing, Universidade Federal de Minas Gerais, Belo Horizonte, Brazil.

${ }^{2}$ Associate Professor, School of Nursing, Universidade Federal de Minas Gerais, Belo Horizonte, Brazil.

${ }^{3}$ Full Professor, Department of Community Healthcare Nursing, School of Nursing, Universidade de São Paulo, São Paulo, Brazil.

${ }^{4}$ Master's Degree Student, Graduate Program in Nursing, School of Nursing, Universidade Federal de Minas Gerais, Belo Horizonte, Brazil.

${ }^{5}$ Assistant Professor, Universidade de Juiz de Fora, Governador Valadares Campus, Minas Gerais, Brazil.

${ }^{6}$ Master's Degree in Nursing, School of Nursing, Universidade Federal de Minas Gerais, Belo Horizonte, Brazil.
}

\begin{abstract}
Objective: To investigate the concept understood by Family Healthcare Strategy (ESF) professionals of knowledge, education and subjects participating in learning activities. Method: Qualitative study carried out with the ESF professionals with university degree, members of the healthcare staff who undertook educational health group activities at Basic Healthcare Units (UBS) in Belo Horizonte. The following triangulation techniques were used: participant observation, photos and field notes; interviews with professionals; and document analysis. Results: We identified three interaction patterns that are different from each other. Firstly, the professional questions, listens and provides information to users, trusting in the transmission of knowledge; secondly, the professional questions and listens, trusting that users can learn from each other; thirdly, the professional questions, listens, discusses and produces knowledge with users, both teaching and learning from each other. Conclusion: There are educational practices that include unique methods capable of creating a militant space for citizenship engagement.
\end{abstract}

\section{DESCRIPTORS}

Health Education; Primary Health Care; Knowledge; Health Personnel.
Correspondence Addressed to:

Maria Flavia Gazzinelli

Departamento de Enfermagem Aplicada,

Escola de Enfermagem, Universidade Federal de Minas Gerais

Av. Alfredo Balena, 190, $5^{\circ}$ andar, sala 508 Santa Efigênia

CEP 30130-100 - Belo Horizonte, MG, Brazil flaviagazzinelli@yahoo.com.br
Received: 07/01/2014

Approved: 01/28/2015 


\section{INTRODUCTION}

In Brazil, public health policies are based on intersectoral actions for the promotion of health to strengthen local management and for social control. Those policies also rely on the need to develop educational activities that may affect the population's health-disease process, while increasing social control to foster quality of life ${ }^{(1)}$.

Accordingly, in the institutional discourse of the Brazilian Ministry of Health, health education is explained as a process of construction and reconstruction of knowledge with a focus on actions that help in developing citizenship, autonomy in meeting the healthcare needs of individuals, groups and communities, and the exercise of social control. (1) For this, health educational practices are encouraged in a dialogical, emancipatory, participatory, and creative manner and anchored in the subjectivity inherent in human beings ${ }^{(1)}$, while approaching the Freirean educational thought.

This project is based on the assumption that critical awareness is developed through dialogue between teacher and students. To Freire, dialogue is a dialectic problem discussion process that involves the commitment of the doer to the process they establish. It is understood that the impulse that leads human beings to dialogue is ontological, i.e., stems from their own nature. "Education as a permanent process is founded in the inconclusiveness of being, which perceives itself as such" (2).

Health education is a strong component of the tasks undertaken by the Family Healthcare Teams (ESF), having as one of its main features the development of group educational activities, commonly known as operative groups, that may affect the population's health-disease process ${ }^{(3)}$ from the following assumptions: the development of individuals' critical awareness about their social environment and their living and health conditions, knowledge sharing derived from experience, as well as the enhancement of collective processes to organize and implement change actions. Furthermore, it presupposes going beyond a preventive perspective and a directive approach, while expanding toward a constructive praxis based on dialogue development ${ }^{(4-6)}$.

What one observes, however, is that often the actions carried out by those teams do not move in this direction since they are focused on the transmission of information within a traditional model that is seldom directed at the development of the autonomy of subjects ${ }^{(7)}$ even though initiatives are acknowledged, both on a national and international level, which attempt at breaking away from a traditional educational model in primary care ${ }^{(8-11)}$.

It is known that the methodological choice for guiding educational practice is based on the concepts of knowledge, education and the subjects that are part of the relationship in educational activity. Such concepts show how education is understood, albeit subconsciously, and define the process in which educational situations are organized and developed. It is also assumed that educational practices can create meeting spaces with the other who is a bearer of different cultures, knowledge and skills. They are also experi- ence sharing spaces for the production of significance that is built within a certain point in time and historical space.

To explain why healthcare professionals adopt or not a dialogical approach to their educational practices, one needs to know what is their concept of knowledge, education and the subjects that are part of the relationship in the learning activity. What one observes in the literature available is that such elements remain obscure in the health education field and emphasis is usually placed on teaching strategies ${ }^{(9-10,12)}$.

Studies designed for educational practices in primary care are often geared to the effects of strategies on a specific event or disease, as well as their respective disorders such as back pain, headache, depression, smoking, and parasites. By focusing on these aspects, such studies leave a gap in understanding the concepts of education, knowledge and the subjects that inform developed educational practices ${ }^{(13-17)}$.

Based on this premise, this study seeks to investigate the concept understood by ESF professionals in Basic Healthcare Units (UBS) with regard to knowledge, education and the subjects participating in learning activities developed by them. For this, educational group activities in basic healthcare units will be analyzed, considering specifically the perspective of the relation between users, health professionals and knowledge. For this analysis, we will adopt the view of some theorists and their proposals.

This study is relevant and justified in that it offers, from the dialogue between theory and practice, signposts that can help health professionals in the development of educational practices in primary care, from a previously established concept of knowledge, education and the subjects that are part of this action, integrated into the objective of learning activities.

\section{METHOD}

A qualitative study carried out with ESF professionals with a university degree, members of the healthcare staff who undertook educational healthcare group activities at Basic Healthcare Units (UBS) in Belo Horizonte in 2011. Participants of group activities were aged between 25 and 60 years old and were predominantly women and residents of low-income communities.

The investigation departed from previous qualitative research, in which one of the objectives was to investigate whether the principle of dialogicity was fostered in educational practices carried out at the UBS in Belo Horizonte. A sample of 20 UBS, drawn randomly and proportionally, was selected from a total of 144 UBS facilities located in Belo Horizonte ${ }^{(8)}$.

Results of the first investigation showed that $32 \%$ of the activities undertaken were dialogic and $66 \%$ non-dialogic, leading to the question of our second study, in which we sought to investigate the concept of knowledge, education and subject among ESF professionals who had performed both dialogic and non-dialogic activities in the first study. Data were collected by the same researcher through various evidence sources, using triangulation techniques of participant observation, photographic records and field notes; interviews with professionals; and document analysis with 
the purpose of deepening the analysis of practices as to the established interaction.

Two nurses, two social workers, two nutritionists, one physiotherapist, one physical educator and one psychologist aged between 25 and 53 were interviewed. Those professionals were responsible for carrying out nine different educational activities at UBS facilities.

Document analysis was undertaken by recording the educational practices developed by the professionals and prioritizing data on planning and the evaluation process. The fact that the records were restricted to the dates of the practices, number of participants and the target audience did not favor the use of such data in the analysis process.

The analysis process was developed through Content Analysis ${ }^{(18)}$ and discussed in light of authors in the health and education fields.

The study was conducted in accordance with the requirements of Resolution No. 196/96 of the Brazilian Health Council, revoked by Resolution No. 466/12, and approved by the Research Ethics Committee ETIC No 0067.0.410.410-10. To distinguish the statements of research subjects and preserve anonymity, health professionals were identified by the letter "P" followed by an ordinary number. Participants of educational group activities were identified by numerical order and different letters of the alphabet, except for the letter "P".

\section{RESULTS}

From the educational practices analyzed, we identified three professional-user-knowledge interaction patterns. To describe and characterize these relationship patterns, a few techniques borrowed from education field researchers were used who studied the interactions within the educational context ${ }^{(19)}$. The patterns were: 1$)$ Interaction pattern represented by Q-L-I (Questions users, Listens to users, Informs users); 2) Q-L interaction pattern (Questions users, Listens to users); and 3) Q-L-D-P interaction pattern (Questions users, Listens to users, Discusses with users, Produces knowledge with users).

In the first pattern, the belief guiding the activity is that the teacher teaches and the student learns. In the second, the belief is that the student learns freely and spontaneously, and in the third, both the teacher and the student teach and learn together ${ }^{(20)}$.

The Q-L-I interaction pattern shows typical situations of educational practices: Diabetes Conversation Group, Seniors Rights Workshop and Expectant Women's Operative Group.

Among such situations, the Diabetes Conversation Group is discussed here and presented in detail. The group is comprised of two men and five women, aged between 30 and 50 years old. The activity begins with an explanation by the health professional on the purpose of the meeting, according to her, it is a chat on Diabetes (P1). The professional then emphasizes the importance of that meeting and that she intends to teach participants a ferw things about Diabetes. Then, she asks users to talk a little about what they understand by Diabetes. They answer: Diabetes is a disease that prevents you from eating things (M1); I feel like I have no disease (C1); For me it's a bad disease that prevents people from eating things and can even kill (F1); It is a plague that prevents me from eating what I want (J1).

During the discussion with users, the professional remains silent. Later, she asks them to position their chairs facing the blackboard, where a poster is hung containing the topics What is Diabetes? Glucose Metabolism, and Blood Sugar Level Balance. She reads out these topics and begins to explain them using scientific terms such as a group of chronic disorders, insulin receptor, molecule produced in the pancreas (P1), without clarifying the meaning of such terms. She does not refer back to the users' previous notion of Diabetes and as she moves from one concept to the other, she uses phrases like: Now that you have understood what Diabetes is, we will learn what glucose metabolism is like (P1). From then on, she repeats the same procedures through to the end of the session.

During the interview with this professional, when asked how she proceeded with her educational activity, she described it as a conversation circle. They are encouraged to express themselves and from their demand, I correct them and teach them what is important from what they said. The purpose of the circle is to provide them with information, discuss the main points and give them the right information (P1).

In the Q-L interaction pattern, we found the following typical situations: Interaction Groups and Living with Quality. The example presented here is the Quality of Life Group, made up of 18 women and two men aged between 30 and 50 years. The health professional initially asks participants to pair up stating that the purpose of the activity is for them to get acquainted and discuss quality of life (P2). She then explains that it is an opportunity for them to express themselves and interact, considering that each one has much to contribute when they work together to improve their quality of life (P2).

While users are talking freely in pairs, she talks with some employees from the Healthcare Unit outside the room where the activity is taking place. A few minutes later, she returns and asks them to introduce themselves to the group and talk about what they have discussed in pairs. The group reports: quality of life is living well (G2); is being bappy (N2); is keeping a healthy diet (F2); is exercising, having a balanced diet and not drinking (M2); quality of life is no smoking, no drugs, no fatty foods and being thin (A2); no diseases (J2); is going out to dance and chat with friends (L2); is keeping healthy and taking strolls (A2).

The professional listens to users talking and asks them what might be needed for them to do those things in practice. Participants answer all at the same time until a female participant speaks up and voices her opinion: my biggest difficulty to put what I want into practice is connected to my emotional problems and depression. When I don't feel well, I don't eat well, I have a poor sleep, I feel pain in my body and a deep sadness (N2). At this point, the professional turns to the group and says: That's it! (P2). She then asks them to talk to each other again. After a while, she wraps up the activity and asks them to continue to reflect at home (P2), and cconcludes the activity with an uplifting song ${ }^{(21)}$. 
When asked about the way she conducts her educational activity, the professional says during the interview: $I$ can see how much the group is a valuable strategy. You get these people to socialize and they really help and take care of each other. I find this very good as many people don't stop to think. They want everything ready for them (...). People forget about their own potential (P2).

In the Q-L-D-P interaction pattern, the following are typical situations: Lian Gong Discussion Groups and Food Education. The Lian Gong Group is the example presented here and the meeting is attended by 18 females aged between 25 and 60 years old. At first, the professional informs participants that the purpose of the activity is for them to talk about and discuss body postures and movements, from [their own] knowledge and how the group performs daily physical activities at home and at work (P3). Then, she plays a song and leads the group into various body movements. Then she asks participants to sit in a circle for Dialogue Time (P3). She asks the group to ponder on their everyday habits and defines habits as something you do routinely without realizing how it is done. What we learn and repeat every day without thinking about how we are doing it (P3).

Then, the professional questions participants on how they have performed their everyday activities and how they see the relationship between those activities and their body. Participants then discuss their professional activities and house chores such as doing the laundry and sweeping the floor: I like cleaning the house, but I hate doing the laundry. My whole body aches when I finish it (N3); I work as a seamstress. I love my job, but I spend too many hours sitting in the same position. It's very uncomfortable for me, so when the day is over I feel very tired and I get stressed out with the kids (T3); I work as a hairdresser and my arms are always sore at the end of the day (M3).

Then, the professional asks participants about their body posture while doing those activities, how often they are performed and the optimal height to place the objects they use in their tasks in relation to their body position. They answer: I have a footrest at home so I can rest my feet when I sit on the couch and they don't dangle. This helps prevent leg pain and improve blood circulation (S3); I remember a homemade foot soak recipe for pain relief and tired feet with lukewarm water, a little salt and a few drops of oil or peppermint essence. You leave your feet soaking in the water for about twenty minutes. This recipe was used by my grandparents and passed on to my mother (T3); Do you know that adding rue and mint leaves to the water is good too? (...) (A3).

The suggestions made by participants are enhanced by the professional, who explains scientifically the use of peppermint, mint and lukewarm water for muscular tension relief. One of the participants speaks up and says that she uses wood blocks to jack her body up and raise her arms to sink height when she is doing the dishes, thus avoiding back pain and injury. Then, another participant demonstrates the exercises she performs every morning to strengthen her back muscles.

The professional highlights the importance of being aware of safety measures to prevent accidents. She reinforc- es the need for the arms to be at optimal height to perform daily activities. She tells participants how small changes to body posture, i.e., when you bend to pick up an object, can make a difference to the body's well-being. Furthermore, she explains the anatomical position and movement of the spine and shows such movements to the group with the help of one of the participants for demonstration. Finally, the professional clarifies aspects of body posture, the main causes associated with cervical column injury and possible disorders resulting therefrom.

During the interview, on talking about the approach used in her educational practice, she reports: I was trying to align their doubts with what they know about the topic, we have to make the most of their knowledge. The Dialogue Time meeting is a space for them to talk and exchange information. I take the opportunity to find out which issues need more attention, and make the necessary comments. We try finding the solutions together. There is no point in my telling them what is right and what is wrong. We have to talk and find solutions together, starting from what they do (P3).

\section{DISCUSSION}

In the first situation concerning the Q-O-I interaction pattern (professional questions, listens to and informs users), user knowledge is considered only as a means to favor the educator to introduce scientific information. In actions thus categorized, professionals choose to guide participants through the educational activity with data that is disconnected from information brought by members of the group. The main goal is to ensure that participants assimilate information considered to be important by the professional. Conflicts are kept hidden in between the amount of knowledge passed on, given that the dominant group takes this knowledge for granted ${ }^{(22)}$. The underlying belief is that knowledge is organized from the outside to inside and that education consists of a series of external outputs which take information to others in order to train them ${ }^{(20)}$.

The method in this case tends to be organized into a relationship system between knowledge and people in a oneway transmission of cultural content by referencing values and standards regarded as ideal. Common sense knowledge is either refused or functionalized ${ }^{(23)}$. Listening to users is not configured as a teaching resource capable of interfering with the development of the teaching action. Listening is a dynamic process that includes the other, both in its cognitive and affective dimensions ${ }^{(2)}$. Such process was absent in this situation. Studies confirm that health professional educators often focus on behavioral change and, to this end, they use persuasion and knowledge transmission techniques ${ }^{(4-6,8-10)}$. The underlying perception in this case is that health education is a strategy to transmit content, provide guidance and teaching mainly with the objective of preventing diseases ${ }^{(4,5)}$.

In the second situation, in the Q-L interaction pattern (professional questions and listens to users), participants are considered the heart of the educational activity and take center stage. In this case, the activity is characterized by the silence of the professional who allows users to talk freely 
in an effort to compel them to assume self-management of the learning situation ${ }^{(20)}$. The underlying idea is that the users' common or routine experience provides a dip into the subjective dimension, therefore resulting in an experience capable of enhancing the signification process. The user is seen as someone who has ready-made innate conceptual schemes. It is up to the professional to allow users to emerge and exert their power.

When participants talk with each other about what they think of quality of life, there is undoubtedly a clash between different types of common sense knowledge that leads to the construction of new knowledge ${ }^{(23)}$. As they interpenetrate each other, these types of knowledge, known as knowledge of realized experiences ${ }^{(2)}$, are responsible for the activation of reciprocal critical processes ${ }^{(24)}$, but still require to dismiss the argument between the professional and participants. In this example situation, the professional goes on to dismiss the argument and the problem discussion and, in doing so, incurs the risk of foregoing what constitutes the key feature of a teaching activity - fostering the learning process. What happened can be named as loss of common experience ${ }^{(22)}$, a process which prevents the conflict between the various types of knowledge, while disabling a more equitable distribution of argumentative skills for different types of knowledge, their interpenetration with each other and overcoming their limits through the strengthening of their potential.

In the third example situation, identified by the Q-L$\mathrm{D}-\mathrm{P}$ interaction pattern (professional questions, listens to, discusses and produces new knowledge with the group), one observes an action directed at the attention of participants, while the professional provides information and answers questions, thus valuing experience sharing.

In the interview with the professional responsible for the Dialogue Time activity, one notes that there is the underlying belief that students will only be able to build new knowledge if they act upon and discuss their problems ${ }^{(20,25)}$. Reports of successful experience in which educators promote teaching activities using the problem discussion method show that the subjects participating in it are not considered mere recipients as they engage in collaborative work with the professional to find solutions to everyday issues ${ }^{(26)}$. Notably, it can be seen that in this educational activity the hierarchy between on who knows and one who does not know is broken, and both parties recognize their different knowledge. There is a reciprocal, less asymmetric relationship between teacher and student, in which both assume commitments and responsibilities, without subordination or juxtaposition, defined by a constitutive relationship ${ }^{(20)}$.

The main feature of this activity is that the professional does impose her knowledge on users and discusses the rationale behind her view and theirs. This happens because she has the inner availability to promote dialogue and, above all, confidence in its emancipatory potential. The epistemological conflict that is established from this action opens up possibilities for users to expand, rework or resignify their findings. Both teacher and students become subjects in this living process and are affected by each other. One could say that a reduction of not knowing areas, of ignorance from both parties occurs here, which leads the educational space to turn into a co-production environment ${ }^{(24)}$.

In order to expand the analysis of these three interaction patterns, it is worth noting the possibilities of understanding the educational process in light of the philosophy of difference ${ }^{(26)}$. In this concept, the encounter between the professional, user and knowledge can be regarded as an event. This means that in the fragments of the daily routine of a healthcare facility an event can erupt - something new, unique, of indefinite course, which is not actually what happens, but focused on what happens. The event does not relate to things, objects and bodies. It is not about the present materiality, or what is visible in the teaching situation. It does not relate to the subjects that are part of it - the professional and the user - nor to those things and objects that compose it. The event is incorporeal, i.e., it is not limited to things or the state of things, nor their quality or physical properties. It cannot be said to exist, but rather that it subsists or persists in their bodies ${ }^{(27)}$.

As it subsists among people, objects, beings, things, etc., the event will always be of unpredictable nature ${ }^{(27)}$. The professional in the third interaction pattern - plan the action, choose the topic and set the provocation that will lead to discussion - cannot predict the course that her activity is taking, since the order of the event is what is to come. The professional's efforts to plan the activity are insufficient to exhaust reality, that which is yet to come. She allows the unexpected to flow in her teaching activity. This attitude is characterized as attention that is open to invention. Allowing it to happen in the action between the professional, user and knowledge goes beyond the expected and breaks up any expectation. This allows the event to be effected.

In the first and second situations presented, there is no room for the incident, the unforeseen to happen. The professionals know in advance the course of their teaching activity, since it is not open to the new and the unexpected, which stems from the crossing of different types of insurgent knowledge. With this, the condition of the event in the teaching situation is lost, namely, that which stops the natural flow of the teaching activity to allow the creation of other senses and problems to be faced.

In the third situation, everything happens when the professional asks users what they do and how they do it on a daily basis. Listening to their grievances, complaints and how to solve them in an inventive way. In this movement, the professional acts as a discourse agent bringing out and filling with significance that which has meaning in itself, considering that meaning is expressed by the event per se. When users bring to mind experiences lived through their bodies and talk about what they do to relieve their pain, new knowledge, what is to come, and new healthcare models are expressed in that collective group.

Within that context, participants are not merely perceived as an interiority or as a tabula rasa. Knowledge is not assimilated from that who knows, as noted in the first situation. It is not seen only as that which exists within, as identified in the second situation. Rather, insurgent knowledge is 
produced from the connections that take place in between, while assuming its inventive, creative, eventful character. When the event erupts, it creates an immanent field for the exercise of thought and alterity. A new space-time for thought and the exercise of subjectivation emerge ${ }^{(27)}$.

Dialogue appears as the major exercise of alterity. Alterity is more than merely acknowledging the right to be different from the other, it is about "desiring encounters with others who might pull us out of the stagnant condition of remaining the same, challenging us into different ways of being in the world"(28). In the first and second situations, whether for the emphasis placed on elaborate knowledge or due to the primacy of common knowledge, the subject's disaccommodation process does not seem to occur. Without disaccommodation, no dialogue as a mode for asserting new forms of subjectivation is possible.

The subjectivation process circulates in social settings and is assumed and experienced by beings by means of an active output that occurs through the multiplicity of components which connect, disconnect and reconnect them ${ }^{(27)}$. Unlike the interaction patterns in the first and second situations, where there are no chance encounters, the events in the third situation can prompt small changes that trigger further actions of knowing and being in the world that go beyond the identitary nexus and analogical and causative concepts. "The individual act becomes collective and every collective act becomes individual (...) there are no subjects, objects or actions centered around one or the other. Instead, there are projects, events, individualities without subject. Every project is collective. Every value is collective. Every failure is also collective."(29)

In educational processes similar to that described in the Q-L-D-P interaction pattern, as exemplified by the third situation, the transformation of reality occurs from the encounter between the affectations and affections emerging from the collective through the power of a revolutionary micro-level policy. It is revolutionary in that a militant educator's action lies in the collective ${ }^{(29)}$. The militant educator seeks to move beyond traditional education which only legitimizes hegemonic scientific knowledge. The event acts in the present, producing possibilities of inventing a fugitive learning space that escapes and resists control. Teacher and student become part of a choir - a polyphony of knowledge, attitudes and stories - that make up the multiplicity of a new territory of praxis and meaning, whereby knowledge is incomplete.

Therefore, capturing the interaction between professionals, participants and knowledge in this study enables the observation that, in the first two interaction patterns (Q-L-I and Q-L), there is no break with the traditional ways of conceptualizing reality, but rather their continuity.

In the Q-L-I interaction pattern, what one sees is the use of participants' knowledge with the previous intention of the professional to correct them and pass on information she deems to be correct. In the Diabetes Conversation Group, when the professional questions users on their knowledge of diabetes and then passes on scientific knowledge on it, only the participants' usual cognitive flow is recorded. They hear an explanation of a subject that they already have some knowledge of. In this circumstance, knowledge is replaced, i.e., repeatedly brought into focus, which can be understood as a recognition process.

In the Q-L interaction pattern, there are no rupture experiences but rather the continuity of previous knowledge. In the Living with Quality activity, where users talk freely about what they think of quality of life, one notes that participants remain closed in their own conceptual world. Therefore, this condition is characterized by not leading to dialogue or knowledge building.

On the other hand, the Q-L-D-P interaction pattern is characterized as an experience to foster dialogue, while breaking up with traditional ways of knowing and creating new ways of thinking and acting ${ }^{(3)}$. In the Dialogue Time activity, the professional makes it happen at a healthcare facility and together with the participants engage in a movement of social and political struggle. This educational activity occurs as a micro-level policy, but has nonetheless the potential to be replicated at a broader educational scale public policies.

Thus, the mere act of knowing can become an act of resistance. The recognition by the other that they are a knowing subject, capable of self-perception of their condition in the world, capable of exercising their human vocation of being more than they are ${ }^{(2)}$ may, in the small, daily world of a healthcare facility, emerge as a form of resistance against established flows and the hegemonic way of doing health education.

But for health education to contribute to increasing the autonomy of people with care needs for the exercise of citizenship and social control, as recommended by public policies, the third situation must be added of the exercise of reflecting on body pains beyond the physical and body realm, while creating for those pains coping strategies that go beyond the technical boundaries. In this sense and in order not to fall short of the purpose of developing autonomy, health education practices cannot forego the discussion on the subjects' lifestyle and social practices. There is an appreciation of this type of educational practice characterized by a proposal for emancipation marked by the indissociability between the epistemological dimension and the political dimension of healthcare ${ }^{(24)}$.

In this respect, health education might become a way of guiding the subjects from a given trajectory point named $i g$ norance, to another point named knowledge. That is, from the path of ignorance, understood as the lack of perception of one's condition, which is a type of colonialism, to a path that presupposes the solidary awareness of the multiple aspects that define people's lifestyles and their everyday activities.

Solidary awareness and emancipatory common sense can only be achieved when different common senses clash to build new knowledge that is also more critical and more powerful, and when meanings are shared and extended from immediate local contexts ${ }^{(23)}$. In such case, educational practices could effectively contribute to the development of new health professional-user relationships, this time consistent with the health education policy guidelines. 


\section{CONCLUSION}

The aim of this research paper is to shed light on the teaching methods used in primary care, while enabling access to different ways on how educational learning situations are conducted. The teaching methods contain underlying concepts of knowledge and the subject. Identifying teaching strategies often becomes insufficient to understand the educational phenomenon, considering that such strategies are only operating components of the methods linked to a set of educational ideas that function as a means to achieve ends. One hopes that this study can contribute to discussions on health education underpinning the Brazilian Ministry of Health purposes and public policies for Health Education.

Moreover, it should be noted the importance of this type of knowledge to resignify the nursing practice, while taking into account the relevance of health education in assisting individuals and communities to maintain and promote health. When health education is developed through listening, problem discussion and joint production of knowledge, it not only manifests itself as an exercise of autonomy, but also furthers the citizenship building process and empowers citizens in the different realms of healthcare and self-care.

\section{RESUMO}

Objetivo: Investigar a concepção de profissionais da Estratégia Saúde da Família (ESF) em relação ao conhecimento, à educação e aos sujeitos que participam de ações pedagógicas. Método: Estudo qualitativo realizado com profissionais da ESF, de nível superior, integrantes da equipe de assistência e que realizaram ações educativas grupais de saúde em Unidades Básicas de Saúde (UBS) de Belo Horizonte. Utilizou-se a triangulação das técnicas: observação participante, fotografia e diário de campo; entrevista com os profissionais; e análise documental. Resultados: Identificaram-se três padrões de interação, diferentes entre si. No primeiro, o profissional questiona, ouve e fornece informações aos usuários, acreditando na transmissão de conhecimentos; no segundo, questiona e ouve, confiando que os usuários aprendem uns com os outros; no terceiro, questiona, ouve, problematiza e produz conhecimentos com os usuários, ambos ensinando e aprendendo. Conclusão: Há práticas educativas que incluem métodos singulares capazes de se transformar em espaço de militância em favor da cidadania.

\section{DESCRITORES}

Educação em Saúde; Atenção Primária à Saúde; Conhecimento; Pessoal de Saúde.

\section{RESUMEN}

Objetivo: Investigar la concepción de los profesionales acerca de la Estrategia Salud de la Família (ESF) con respecto al conocimiento, la educación y los sujetos que participan de acciones pedagógicas. Método: Estudio cualitativo realizado con profesionales de la ESF, de nivel superior, integrantes del equipo de asistencia y quienes llevaron a cabo acciones educativas grupales de salud en Unidades Básicas de Salud (UBS) de Belo Horizonte. Se utilizó la triangulación de las técnicas; observación participante, fotografía y diario de campo; entrevista con los profesionales y análisis documental. Resultados: Se identificaron tres estándares de interacción, diferentes entre sí. En el primero, el profesional cuestiona, oye y facilita informaciones a los usuarios, creyendo en la transmisión de conocimientos; en el segundo, cuestiona y oye, fiándose de que los usuarios aprenden los unos con los otros; en el tercero, cuestiona, oye, problematiza y produce conocimientos con los usuarios, ambos enseñando y aprendiendo. Conclusión: Existen prácticas educativas que incluyen métodos singulares capaces de convertirse en espacio de militancia a favor de la ciudadanía.

\section{DESCRIPTORES}

Educación en Salud; Atención Primaria de Salud; Conocimiento; Personal de Salud.

\section{REFERENCES}

1. Brasil. Ministério da Saúde. Portaria n. 2.488, de 21 de outubro de 2011. Aprova a Política Nacional de Atenção Básica, estabelecendo a revisão de diretrizes e normas para a organização da Atenção Básica, para a Estratégia Saúde da Família (ESF) e o Programa de Agentes Comunitários de Saúde (PACS) [Internet]. Brasília; 2011. [citado 2014 mar. 14]. Disponível em: http://bvsms.saude.gov.br/bvs/saudelegis/ gm/2011/prt2488_21_10_2011.html

2. Freire P. Pedagogia da autonomia: saberes necessários à prática educativa. 39aa ed. São Paulo: Paz e Terra; 1996.

3. Mascarenhas NB, Melo CMM, Fagundes NC. Produção do conhecimento sobre promoção da saúde e prática da enfermeira na atenção Primária. Rev Bras Enferm. 2012;65(6):991-9.

4. Machado MFAS, Monteiro EMLM, Queiroz DT, Vieira NFC, Barroso MGT. Integralidade, formação de saúde, educação em saúde e as propostas do SUS: uma revisão conceitual. Ciênc Saúde Coletiva. 2007;12(2):335-42.

5. Sousa LB, Torres CA, Pinheiro PNC, Pinheiro AKB. Práticas de educação em saúde no Brasil: a atuação da enfermagem. Rev Enferm UERJ [Internet]. 2010 [citado 2014 mar. 14];18(1):55-60. Disponível em: http://www.facenf.uerj.br/v18n1/v18n1a10.pdf

6. Leonello VM, Oliveira MAC. Competencies for educational activities in nursing. Rev Latino Am Enfermagem. 2008;16(2):177-83.

7. Alves GG, Aerts D. As práticas educativas em saúde e a Estratégia de Saúde da Família. Ciênc Saúde Coletiva. 2011;16(1):319-25.

8. Carneiro ACLL, Souza V, Godinho LK, Faria ICM, Silva KL, Gazzinelli MF. Educação para a promoção da saúde no contexto da atenção primária. Rev Panam Salud Publica. 2012;31(2):115-20.

9. Silva P, Dias MSA, Rodrigues AB. Práxis educativa em saúde dos enfermeiros da Estratégia Saúde da Família. Ciênc Saúde Coletiva. 2009;14(1):1453-62. 
10. Trapé CA, Soares CB. Educative practice of community health agents analyzed through the category of praxis. Rev Latino Am Enfermagem. 2007;15(1):142-9.

11. Cano Fuentes G, Dastis Bendala C, Morales Barroso I, Manzanares Torné ML, Fernández Gregorio A, Martín Romana L. A rondomised clinical trial to evaluate the effectiveness of an educational intervention developed for adult asthmatics in a primary care centre. Aten Primaria. 2014;46(3):117-39.

12. Salci MA, Maceno P, Rozza SG, Silva DMGV, Boehs AE, Heidemann ITSB. Educação em saúde e suas perspectivas teóricas: algumas reflexões. Texto Contexto Enferm. 2013;22(1):224-30.

13. Díaz-Cerrillo JL, Rondón-Ramos A. Design of an educational tool for Primary Care patients with chronic non-specific low back pain. Aten Primaria. 2014;47(2):117-23.

14. Braschinsky M, Haldre S, Kals M, Lofik A, Kivisild A, Korjas J, et al. EHMTI-o259. Demonstrational project: to develop, implement and test an educational model for better headache-related primary health care. J Headache Pain. 2014;15 Suppl 1:D3.

15. Garcia-Ortega I, Rodriguez J, Escobar-Martinez A, Kutcher S. Implementing an educational program to enhance identification, diagnosis and treatment of adolescent depression into Primary Care in Guatemala. Fam Med Medical Sci Res. 2013;2(1):1000104.

16. Chamberlain C, O'Mara-Eves A, Oliver S, Caird J, Perlen S, Eades S et al. Psychosocial interventions for supporting women to stop smoking in pregnancy. Cochrane Database Syst Rev. 2013;(10):CD001055.

17. Vasconcelos EM. Popular education as a tool for redirecting strategies to deal with infectious and parasitic disease. Cad Saúde Pública. 1998;14(2):39-57.

18. Bardin L. Análise de conteúdo. Lisboa: Edições 70; 2004.

19. Mortimer EF, Scott P. Atividade discursiva nas salas de aula de ciências: uma ferramenta sociocultural para analisar e planejar o ensino. Invest Ensino Ciênc [Internet]. 2002 [citado 2014 mar. 14];7(3):283-306. Disponível em: http://www.if.ufrgs.br/ienci/artigos/Artigo_ID94/ v7_n3_a2002

20. Not L. As pedagogias do conhecimento. $2^{\text {a }}$ ed. Rio de Janeiro: Bertrand; 1991.

21. Gonzaguinha. O Que É, O Que É? [CD]. Rio de Janeiro: Som Livre; 2004.

22. Santos BS. Para uma pedagogia do conflito. In: Freitas ALS, Moraes SC, organizadores. Contra o desperdício da experiência: a pedagogia do conflito revisitada. Porto Alegre: Redes Ed.; 2009. p. 15-40.

23. Santos BS. A crítica da razão indolente: contra o desperdício da experiência: para um novo senso comum. $4^{\mathrm{a}}$ ed. São Paulo: Cortez; 2002.

24. Santos BS. Um discurso sobre as ciências. $2^{\text {a }}$ ed. São Paulo: Cortez; 2004.

25. Becker F. Educação e construção do conhecimento. Porto Alegre: Artmed; 2001. Modelos pedagógicos e modelos epistemológicos; p. $15-32$.

26. Pedrosa KKA, Castro LO, Pereira W. Enfermagem e educação em saúde na Atenção Básica: uma experiência no Bairro de Mãe Luíza, Natal, RN. R Pesq Cuid Fundam. [Internet]. 2012 [citado 2014 mar. 16];4(4):2806-15. Disponível em: http://www.seer.unirio.br/index. $\mathrm{php} /$ cuidadofundamental/article/view/1603/pdf

27. Deleuze G. Lógica do sentido. $2^{\text {a }}$ ed. São Paulo: Perspectiva; 1988.

28. Dinis NF. Educação, cinema e alteridade. Educar (Curitiba) [Internet]. 2005 [citado 2014 mar. 16];26(1):67-79. [citado 2014 mar. 16]. Disponível em: http://educa.fcc.org.br/pdf/er/n26/n26a06.pdf

29. Gallo S. Deleuze e a educação. 2ª ed. Belo Horizonte: Autêntica; 2008. 